\title{
The use of Acinetobacter sp. for oil hydrocarbon degradation in saline waters
}

\author{
Elnara Fatajeva ${ }^{1,3}$, \\ Indrẻ Gailiūtè $\dot{\dot{x}}^{3,4}$, \\ Dainius Paliulis ${ }^{1}$, \\ Saulius Grigiškis ${ }^{2,3}$ \\ ${ }^{1}$ Vilnius Gediminas Technical University, \\ Faculty of Environmental Engineering, \\ Department of Environmental Protection, \\ Saulètekio ave. 11, LT-10223 Vilnius, Lithuania \\ ${ }^{2}$ Vilnius Gediminas Technical University, \\ Faculty of Fundamental Sciences, \\ Department of Chemistry and Bioengineering, \\ Sauletekio ave. 11, LT-10223 Vilnius, Lithuania \\ ${ }^{3}$ JSC "Biocentras", \\ V. A. Graičiūno str. 10, LT-02241 Vilnius, Lithuania \\ ${ }^{4}$ Vilnius University, \\ Institute of Biotechnology, \\ V. A. Graičiūno str. 8, LT-02241 Vilnius, Lithuania
}

This paper describes the problem of oil pollutant removal and the use of Acinetobacter genus microorganisms in oil biodegradation. As part of the experiments, Acinetobacter genus microorganism strain with the best ability to degrade crude oil and fuel oil in saline waters was selected from the microorganism collection of JSC "Biocentras". The impact of environmental conditions (salinity, temperature, $\mathrm{pH}$, substrate concentration) on this strain's viability and the efficacy of its oil degradation processes were evaluated. The most efficient degradation of oil products by Acinetobacter genus bacteria was at temperature of $30^{\circ} \mathrm{C}$, in a $\mathrm{pH}$ range of $7-8$, in model ocean water of $35 \%$ salinity.

Key words: Acinetobacter sp., oil hydrocarbons, degradation, saline water, marine oil spill

\section{INTRODUCTION}

Up to these days oil and its products remain the main energy source in industry and daily life (Das et al., 2011). With an increased scope of oil and its products production and consumption comes the increased threat of pollution (BP Statistical Review, 2013). Upon the release of oil or its products into the water ecosystem, the damage is felt not only by the smallest organisms (algae, bacteria, protozoa), but also by water plants, fish, birds and mammals. Water ecosystem is especially sensitive to any amount of oil, its products or other harmful materials, as organisms want to accumulate oil compounds within themselves
(Response to spills..., 2014). Oil and its products can affect the reproduction, growth or behaviour characteristics of many animals even at small pollutant concentrations.

Various physical, chemical and biological methods are used to remove pollutants from the environment, however, from the environmental protection perspective biological oil pollutant removal method is the most suitable, as it is relatively cheap and the process does not expel secondary pollutants (Fathepure, 2014; Bao et al., 2012; Liu et al., 2011).

Biodegradation is a natural process (Venosa et al., 2003; Čipinytè et al., 2000). The most prevalent bacteria in places polluted with oil are 
those of genera Rhodococcus, Pseudomonas, Arthrobacter, Acinetobacter (Jankevičius et al., 2003).

The intensity of biodegradation is influenced by several factors, such as nutrients, oxygen, $\mathrm{pH}$-value, composition, concentration and bioavailability of the contaminants. Temperature plays a significant role in controlling the nature and the extent of microbial hydrocarbon metabolism (Margesin, 2012).

However, application of microbial technologies for treating contaminated high salinity or fluctuating salinity environment is limited due to the detrimental effects of salt on microbial life including disruption cell membrane, denaturation of enzymes, low solubility of oxygen, low solubility of hydrocarbons, and desiccation (Fathepure, 2014).

It is well known that oil-degrading bacteria occur extensively in a wide variety of environments, including sediments and the water column. The use of native or ndigenous microbiota for bioremediation is of great interest since it is often more useful and beneficial than commercial inoculants (Rocha et al., 2013).

Microorganisms of genus Acinetobacter which are used in this work are aerobic, nonmotile, gram-negative bacteria. Their optimal growth temperature is $33-35{ }^{\circ} \mathrm{C}$. The bacteria of this genus can break down alkanes with a chain length of $\mathrm{C}_{10}$ to $\mathrm{C}_{40}$. The degradation intensity of hydrocarbons depends on the initial medium $\mathrm{pH}$, temperature, initial substrate concentration, etc. (Doughari et al., 2011; Ron et al., 2010).

Literature sources note that the highest substrate degradation degree is obtained in the seas when the temperature fluctuates between $+15^{\circ} \mathrm{C}$ and $+20^{\circ} \mathrm{C}$ (Venosa et al., 2003), however, oil hydrocarbon degradation degree at different temperatures also depends on microorganism type, degradation medium, constitution, and physical properties and chemical composition of the hydrocarbon mix (Venosa et al., 2003; Leahy et al., 1990). It has also been determined that the optimal temperature for operation of oil oxidizing microorganisms is between $+30{ }^{\circ} \mathrm{C}$ and $+40^{\circ} \mathrm{C}$, when the high- est degradation degree is reached. Oil toxicity increases when temperature rises above $+40{ }^{\circ} \mathrm{C}$ and that can inhibit the biological degradation process (Venosa et al., 2003).

Another no less important factor for oil hydrocarbon degradation is water $\mathrm{pH}$. Likewise salinity, $\mathrm{pH}$ cannot fluctuate within large intervals in seas and oceans (Westermeyer, 1991). Most often sea water $\mathrm{pH}$ is between 7.5 and 8.4. Oil oxidizing microorganisms can degrade oil hydrocarbons in a relatively wide range (5.0 to 10.0), but the optimal medium $\mathrm{pH}$ is between 7.0 and 8.0 (Prabhakaran et al., 2014).

One more factor important for the successful degradation process is substrate concentration. At a too high substrate concentration it can become cytotoxic, because the oxidation process produces toxic metabolites and the cells die. Too low substrate concentration can also slow down the biological degradation process, as there will not be enough oil oxidizing microorganisms and degradation will be ineffective (Prince et al., 2013). The degradation of heavy hydrocarbons can be impeded by intermediary degradation products, thus it is important to determine the influence of hydrocarbon substrate on microorganism strain oxidizing properties in model sea water of $35 \%$ salinity. So, while choosing a biological treatment method it is important not only to determine environmental factors able to decrease the degradation efficacy, but also to evaluate the substrate concentration in order to pick up a suitable microorganism amount (Gavrilescu, 2013).

The goal of this work is to choose a strain best suitable to degrade oil hydrocarbons in waters of different salinity from JSC "Biocentras" microorganism collection, and to determine appropriate conditions for substrate degradation.

\section{MATERIALS AND METHODS}

Microorganisms. The following strains of hydrocarbon degrading bacteria obtained from culture collection of JSC "Biocentras" were 
used: Pr82; N3; NJ5. In publications up to 2014 these bacterial strains were assigned to the genus Arthrobacter (established with a microbiological method). After sequencing bacterial strains Pr82; N3; NJ5 assigned to the genus Acinetobacter.

Simulants sea and ocean waters. $3.5 \%$ sea water composition $(\mathrm{mg} / \mathrm{kg} / / \% 0): 1954\left(\mathrm{Cl}^{-}\right)$; $975\left(\mathrm{Na}^{+}\right) ; 316\left(\left(\mathrm{SO}_{4}\right)^{2-}\right) ; 127\left(\mathrm{Mg}^{2+}\right) ; 45\left(\mathrm{Ca}^{2+}\right)$; $48\left(\mathrm{~K}^{+}\right) ; 20\left(\left(\mathrm{HCO}_{3}\right)^{-}\right)$.

$35 \%$ sea water composition $(\mathrm{mg} / \mathrm{kg} / / \% \mathrm{o})$ : $19538 \quad\left(\mathrm{Cl}^{-}\right) ; \quad 9750 \quad\left(\mathrm{Na}^{+}\right) ; \quad 3158 \quad\left(\left(\mathrm{SO}_{4}\right)^{2-}\right)$; $1266\left(\mathrm{Mg}^{2+}\right) ; 450\left(\mathrm{Ca}^{2+}\right) ; 481\left(\mathrm{~K}^{+}\right) ; 204\left(\left(\mathrm{HCO}_{3}\right)^{-}\right)$.

$35 \%$ ocean water composition $(\mathrm{mg} / \mathrm{kg} / / \% \mathrm{o})$ : $19353 \quad\left(\mathrm{Cl}^{-}\right) ; 10760 \quad\left(\mathrm{Na}^{+}\right) ; 2712 \quad\left(\left(\mathrm{SO}_{4}\right)^{2-}\right)$; $1294\left(\mathrm{Mg}^{2+}\right) ; 413\left(\mathrm{Ca}^{2+}\right) ; 387\left(\mathrm{~K}^{+}\right) ; 142\left(\left(\mathrm{HCO}_{3}\right)^{-}\right)$.

Preparation of inoculum. $250 \mathrm{ml}$ flask with $100 \mathrm{ml}$ of sterile liquid nutrient medium was seeded with the frozen microorganism suspension using an inoculation loop in a laminar flow cabinet. It was incubated in a rotary shaker at temperature of $30{ }^{\circ} \mathrm{C}$ with $200 \mathrm{rpm}$ for 18 hours.

Determination of live cell count by seeding on solid nutrient medium. This method allows to count live microorganism cells in a sample (Gedminiene, 2006). $1 \mathrm{ml}$ of the sample is diluted with physiological saline $(0.9 \%$ $\mathrm{NaCl}, 9 \mathrm{ml}$ each) in the prepared test tubes. $100 \mu \mathrm{L}$ of adequately diluted substance is pipetted onto agarized mineral medium with $100 \mu \mathrm{L}$ of diesel in a Petri dish. The sample is evenly layered onto the medium with a spreader. Culture is grown at temperature of $30^{\circ} \mathrm{C}$ for 2 days. Grown colonies are counted (CFU/ml) after two days, taking the dilution into account (Gedminienè, 2006).

Selection of the best oil and fuel oil degrading microorganism strain. Experiments were performed in liquid sterile water media of different salinity (3.5\% and $35 \%$ sea and $35 \%$ ocean), while using crude oil and fuel oil as substrates $(2.0 \mathrm{~g} / \mathrm{L})$. Samples $(5 \mathrm{ml}$ inoculate in $50 \mathrm{ml}$ of media with substrate) are incubated for 4 days at temperature of $30{ }^{\circ} \mathrm{C}$ while agitating at $200 \mathrm{rpm}$. A sample of analysis water with oil is prepared for comparison. Activity of oil degrading hydrocarbon strains is evaluated upon calculating the degree of substrate degradation. One strain of genus Acinetobacter is chosen as the best one to degrade hydrocarbon substrates.

Determination of oil hydrocarbon concentration in samples of simulating sea and ocean water before and after biological degradation. Hydrocarbon concentration in control samples and in samples after biological degradation is determined by infrared spectrophotometry. Samples are acidified to $\mathrm{pH} 2.0$ or lower with a diluted solution of hydrochloric acid (ratio 1:1). In order to prevent the formation of emulsions or to decrease its quantity, $5 \mathrm{~g}$ of magnesium sulphate is added to the acidified sample. After adding $10 \mathrm{ml}$ of chloroform, the sample is agitated in a shaker $(200 \mathrm{rpm})$ and then poured into a separator funnel and left to set. Chloroform phase with solutes (extract) is separated. Remaining lipophilic compounds in a separated water phase are extracted again. Organic compound extracts in chloroform are mixed together and centrifuged at $4000 \times \mathrm{g}$ for $2 \mathrm{~min}$; thus the remaining water phase is separated.

The extract is supplemented with $5 \mathrm{~g}$ of aluminium oxide and $5 \mathrm{~g}$ of anhydrous sodium sulphate, suspended and left for $10 \mathrm{~min}$. The extract is centrifuged at $4000 \times \mathrm{g}$ for $2 \mathrm{~min}$ and poured into a clean test tube which is corked.

The extract is diluted 10 times with chloroform. Cuvette is filled with $100 \mu \mathrm{L}$ of the extract and the solvent is evaporated. The sample is measured at a fixed wavelength $-2924 \mathrm{~cm}^{-1}$. The amount of oil products is determined by a calibration curve.

Evaluation of hydrocarbon substrate degradation rate. After biological degradation, substrate degradation degree is evaluated in percent (\%) and calculated according to the formula:

$$
\operatorname{SDD}(\%)=100 \%-\left(\frac{\mathrm{C}_{2} \times 100 \%}{\mathrm{C}_{1}}\right)
$$

Here: SDD - hydrocarbon substrate degradation degree, \%; $\mathrm{C}_{1}$ - primary hydrocarbon substrate concentration in the sample, $\mathrm{mg} / \mathrm{l}$; $\mathrm{C}_{2}$ - hydrocarbon substrate degradation degree in the sample after the biological degradation, $\mathrm{mg} / \mathrm{l}$. 


\section{Selection of conditions for substrate degra-} dation

Study of substrate degradation rate dependency on temperature. Experiments, regarding the best hydrocarbon substrate degrading strain's dependency on the temperature in model $35 \%$ ocean water, are performed at temperatures of $+4{ }^{\circ} \mathrm{C},+15{ }^{\circ} \mathrm{C}$ and $+30{ }^{\circ} \mathrm{C}$, when primary concentration of substrate (crude oil) is $2.0 \mathrm{~g} / \mathrm{L}$.

Study of substrate degradation rate dependency on $\boldsymbol{p H}$. Experiments, regarding substrate degradation degree dependency on $\mathrm{pH}$ in model $35 \%$ ocean water, are performed by choosing $\mathrm{pH}$ values of $5.0 ; 6.0 ; 7.0 ; 8.0 ; 9.0$; 10.0 , when primary concentration of substrate (oil) is $2.0 \mathrm{~g} / \mathrm{L}$.

Study of substrate degradation rate dependency on the substrate concentration. Substrate concentrations of $1.0 ; 2.0 ; 3.0 ; 5.0 ; 7.0$; $10.0(\mathrm{~g} / \mathrm{L})$ are chosen for the experiments. The experiment is performed in model $35 \%$ ocean water.

All the experiments lasted for 4 days, while agitating the samples at $200 \mathrm{rpm}$. Upon determining the substrate degradation temperature, all the other experiments are performed at that temperature. Activity of oil hydrocarbon degrading strains is evaluated by calculating substrate degradation degree and the amount of oil-oxidizing microorganism.

\section{RESULTS}

\section{Selection of microorganism strain best suited for oil degradation}

The specificity of the selected Acinetobacter species strains (Pr82, NJ5 and N3) displayed while degrading oil in waters of various salinities was analyzed during the second stage of the research.

The activity of oil hydrocarbon degrading strains is evaluated by calculating the amount of degraded substrate.

Within the interval of 4 days all three strains degraded oil quite differently. Oil degradation degree fluctuated from $9.68 \%$ to $31.6 \%$.

Oil was best degraded in model ocean water of $35 \%$ salinity. The degradation degree for
Pr82 strain in this medium was $24.7 \pm 5.6 \%$, for NJ5 it was $23.3 \pm 1.4 \%$, for N3 $-31.6 \pm 1.4 \%$. The degradation degree for Pr82 strain on model sea water of $3.5 \%$ salinity was $12.4 \pm 4.2 \%$, for NJ5 it was $21.0 \pm 0.6 \%$, for N3 $-14.4 \pm 3.7 \%$. The degradation degree for Pr82 strain on model sea water of $35 \%$ salinity was $9.68 \pm 3.7 \%$ of oil, for NJ5 it was $10.1 \pm 4.3 \%$, for N3 it was $16.8 \pm 4.8 \%$.

N3 strain degraded oil worse than NJ5 only in model sea water of $3.5 \%$ salinity, however, the difference was miniscule - merely $6.6 \%$.

Two microorganism strains NJ5 and N3 degrading oil best in the media of three different salinities were selected for the next research stage upon evaluating the oil degradation degree (Fig. 1).

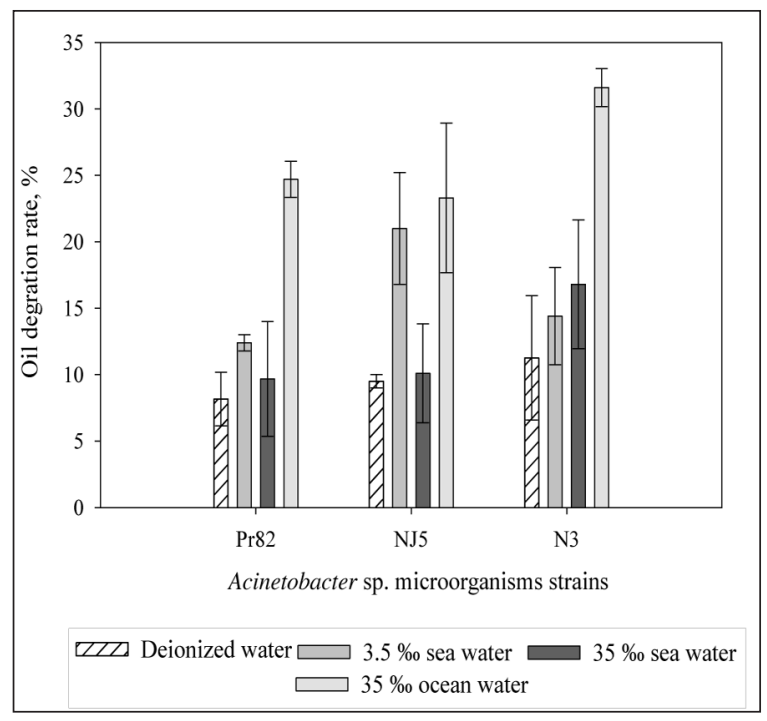

Fig. 1. Oil degradation rate by Acinetobacter sp. Pr82, NJ5 and N3 strains in model waters of various salinities

\section{Selection of microorganism strain best suited for fuel oil degradation}

The selected Acinetobacter sp. NJ5 and N3 strains degraded fuel oil worse than oil.

Fuel oil showed the best degradation in model ocean water of $35 \%$ salinity. The fuel oil degradation degree for NJ5 strain in this medium was $18.7 \pm 3.5 \%$, for $\mathrm{N} 3$ it was $26.7 \pm 4.6 \%$. The degradation degree in model sea water of $3.5 \%$ 
salinity for NJ5 strain was only $3.37 \pm 0.09 \%$, and for N3 strain it was $11.3 \pm 2.5 \%$. The degradation degree in model sea water of $35 \%$ salinity for NJ5 strain was $6.25 \pm 0.7 \%$ of fuel oil, and for N3 it was $15.3 \pm 3.7 \%$.

Acinetobacter sp. N3 strain degraded fuel oil much better in model sea waters, but in the model ocean water this strain degraded less substrate than NJ5.

Compounds of a large molecular mass present in fuel oil are harder to oxidize, thus these genus Acinetobacter strains, which effectively degraded not only oil but also fuel oil, can be employed to clean waters from oil hydrocarbons in the future.

The genus Acinetobacter N3 strain was selected for further studies. Upon determining that Acinetobacter sp. strains NJ5, N3 and Pr82 best degrading oil hydrocarbons in model $35 \%$ ocean water for the next research stage were performed model ocean water of $35 \%$ salinity (Fig. 2).

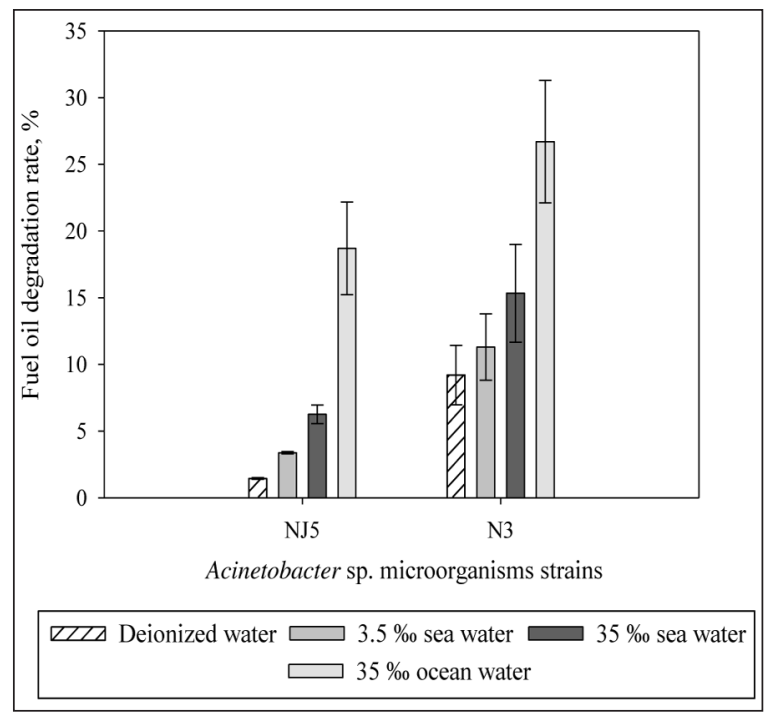

Fig. 2. Fuel oil degradation rate by Acinetobacter sp. NJ5 and N3 strains in model waters of various salinities

\section{Dependency of oil degradation by Acineto- bacter sp. N3 strain on temperature}

After the analysis of the research results it was determined that at temperature of $+4{ }^{\circ} \mathrm{C}$ oil degradation degree is $7.6 \pm 1.9 \%$, at $+15^{\circ} \mathrm{C}$ it is $17.4 \pm 1.5 \%$, at $+30{ }^{\circ} \mathrm{C}-20.9 \pm 1.7 \%$ (Fig. 3 ).

During the research, microorganism cell count was also evaluated. It was determined that the microorganism count grows as the temperature increases. The maximal microorganism cell count $\left(20.0 \cdot 10^{6} \pm 1.7 \mathrm{CFU} / \mathrm{ml}\right)$ was obtained at temperature of $+30{ }^{\circ} \mathrm{C}$. The established substrate degradation degree was also highest $(20.9 \pm 1.7 \%)$ at this temperature. As the temperature rises from $+4{ }^{\circ} \mathrm{C}$ to $+30{ }^{\circ} \mathrm{C}$, $\mathrm{N} 3$ strain cell count also increases from $13.7 \cdot 10^{6} \pm 1.6$ to $20 \cdot 10^{6} \pm 1.7 \mathrm{CFU} / \mathrm{ml}$. Upon evaluating the dependency of substrate degradation degree of temperature, it was observed that N3 strain degrades oil best at temperature of $+30{ }^{\circ} \mathrm{C}$ (Fig. 4).

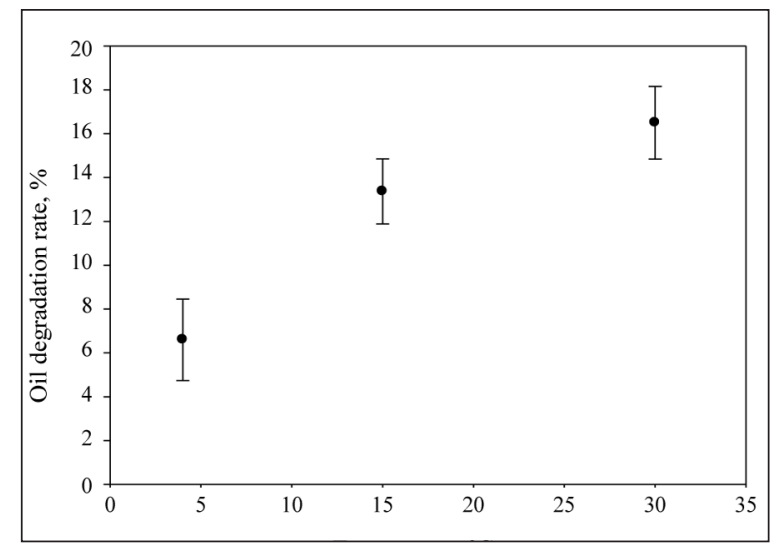

Fig. 3. Dependency of substrate degradation rate on temperature by Acinetobacter sp. N3

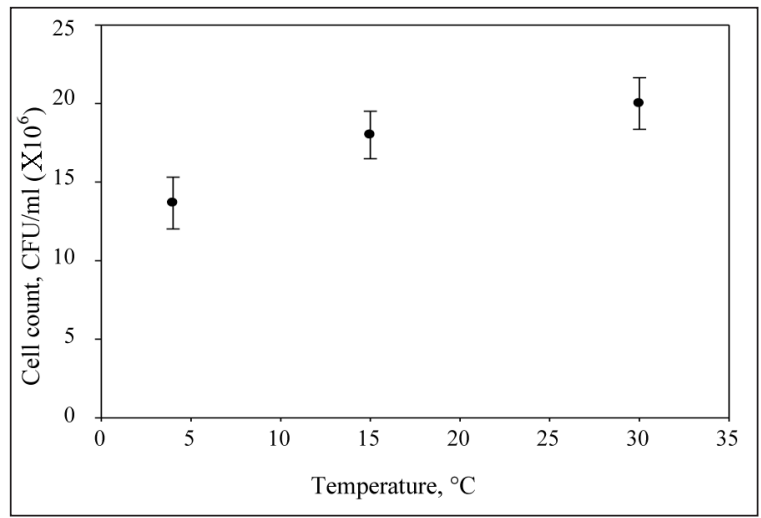

Fig. 4. Dependency of cell count on temperature by Acinetobacter sp. N3 
Upon summarizing and evaluating the study results, further investigations into the dependency on $\mathrm{pH}$ and substrate concentration were performed in model ocean water of $35 \%$ salinity at temperature of $+30^{\circ} \mathrm{C}$.

\section{Dependency of oil degradation by Acineto- bacter sp. $\mathrm{N} 3$ strain on $\mathrm{pH}$}

The results of the dependency of oil degradation degree and live cell count of Acinetobacter sp. N3 on $\mathrm{pH}$ were obtained.

The obtained results show that oil degradation degree increases (from $4.3 \pm 1.4 \%$ to $15.9 \pm 2.1 \%)$ in a pH range of 5.0 to 8.0 and decreases (from $15.9 \pm 2.1 \%$ to $3.7 \pm 0.9 \%$ ) in a $\mathrm{pH}$ range of 8.0 to 10.0. The highest oil degradation degree (15.9\%) was reached at $\mathrm{pH}$ 8.0. At neutral medium $\mathrm{pH}$ of 7.0 substrate degradation degree was $13.7 \pm 1.9 \%$ (Fig. 5).

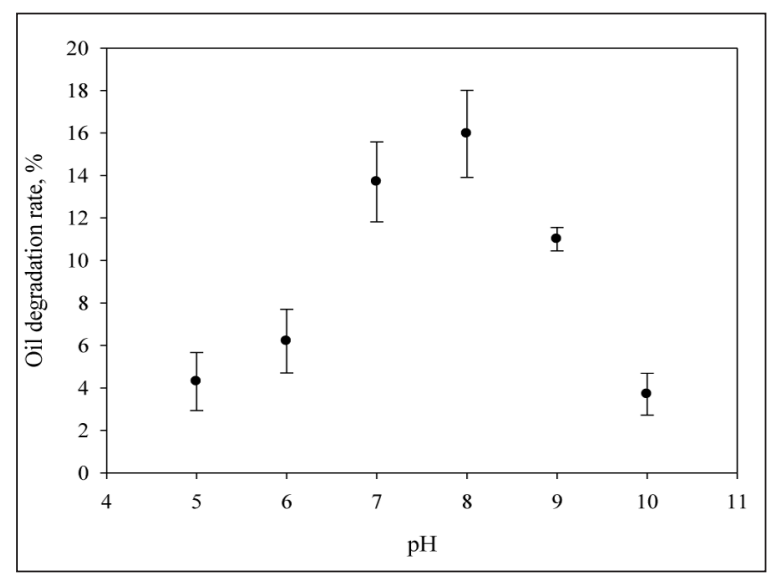

Fig. 5. Dependency of substrate degradation rate on initial medium $\mathrm{pH}$ in model ocean water of $35 \%$ salinity by Acinetobacter sp. N3

An analogous tendency was observed while investigating the influence of initial medium $\mathrm{pH}$ on live cell count of $\mathrm{N} 3$ strain. It was determined that the cell count in a $\mathrm{pH}$ range from 5.0 to $8.0 \mathrm{in}$ creased from $12.6 \cdot 10^{6} \pm 1.5$ to $33 \cdot 10^{6} \pm 3.0 \mathrm{CFU} /$ $\mathrm{ml}$ and after that fractionally decreased in the $\mathrm{pH}$ range from 8.0 to 10.0 . The maximal N3 cell count $\left(33 \cdot 10^{6} \pm 3.0 \mathrm{CFU} / \mathrm{ml}\right)$ was observed at $\mathrm{pH}$ 8.0. The maximal oil degradation degree was also observed at the same conditions (Fig. 6).

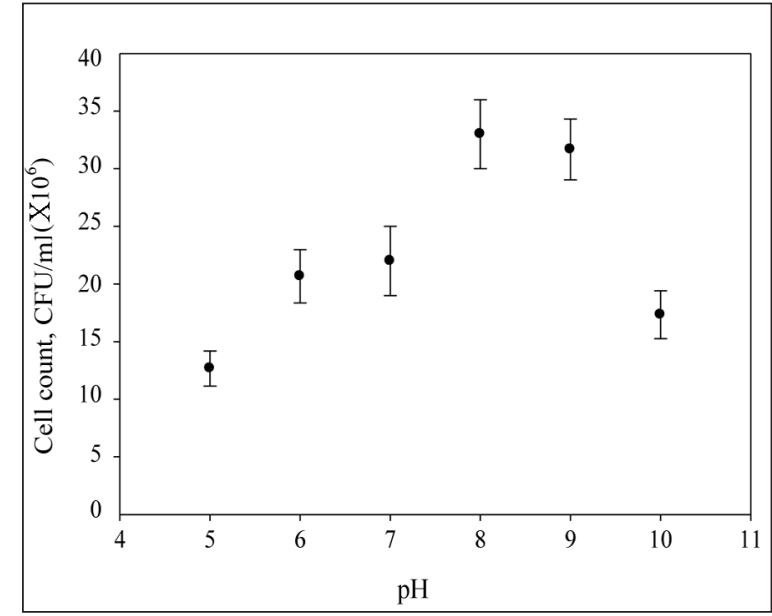

Fig. 6. Dependency of cell count on initial medium $\mathrm{pH}$ in model ocean water of $35 \%$ salinity by Acinetobacter sp. N3

\section{Dependency of oil degradation by Acinetobac- ter sp. N3 strain on substrate concentration} Increasing the initial oil concentration from 1.0 to $2.0 \mathrm{~g} / \mathrm{l}$, the oil degradation degree also increased. Further increasing the oil concentration up to $10.0 \mathrm{~g} / \mathrm{l}$ oil degradation degree decreased. The highest substrate degradation degree $(16.2 \pm 1.8 \%)$ was obtained at the oil concentration of $2.0 \mathrm{~g} / \mathrm{l}$; the lowest degradation degree $(2.7 \pm 1.5 \%)$ was observed when the oil concentration in the medium was $10.0 \mathrm{~g} / \mathrm{L}$. At the lowest initial oil concentration $(1.0 \mathrm{~g} / \mathrm{L}), 15.8 \pm 1.5 \%$ of substrate was degraded after 4 days (Fig. 7).

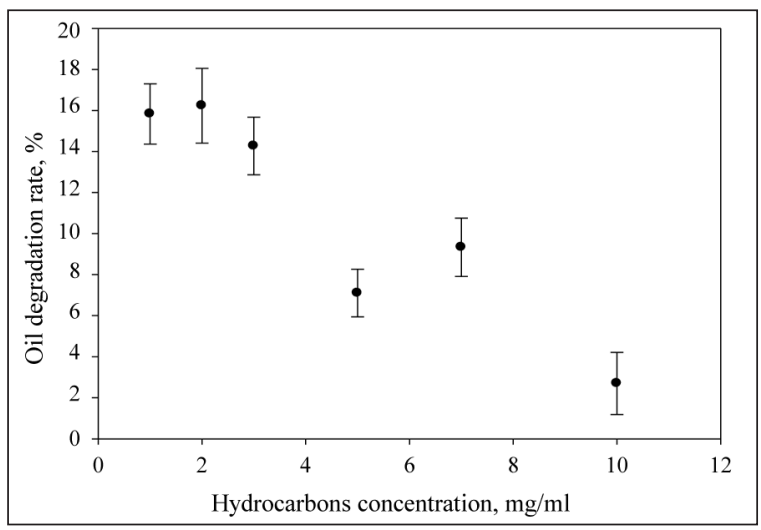

Fig. 7. Dependency of substrate degradation rate on hydrocarbons concentration in model ocean water of $35 \%$ salinity by Acinetobacter sp. N3 
The lowest live cell count $\left(42 \cdot 10^{6} \pm 2.6 \mathrm{CFU} /\right.$ $\mathrm{mL}$ ) was observed at an initial oil concentration of $1.0 \mathrm{~g} / \mathrm{L}$. As a substrate concentration increases, live cell count of N3 strain also increases (Fig. 8).

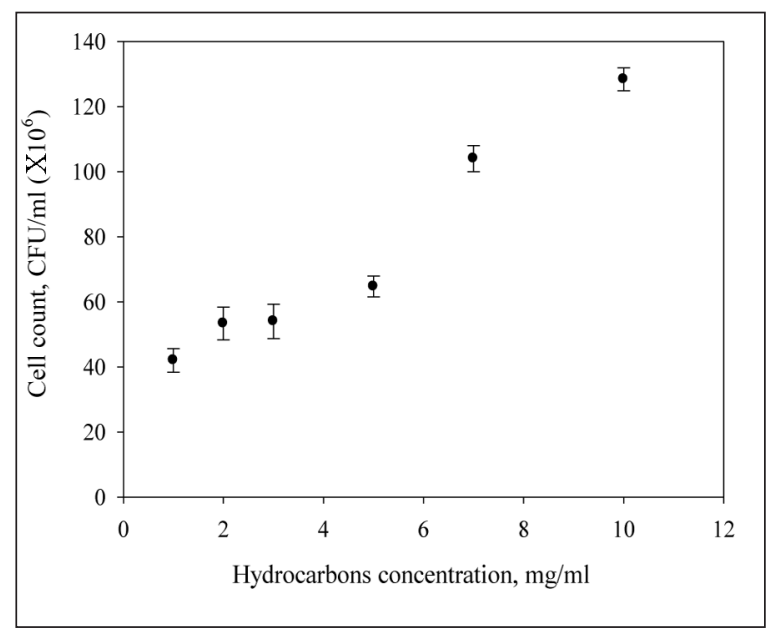

Fig. 8. Dependency of cell count on hydrocarbons concentration in model ocean water of $35 \%$ salinity by Acinetobacter sp. N3

\section{CONCLUSIONS}

The most efficient oil degradation level in model waters of varied salinity was reached by Acinetobacter sp. NJ5 and N3 strains.

- The most efficient fuel oil degradation level in model waters of varied salinity was reached by Acinetobacter sp. N3 strain.

- The temperature $30^{\circ} \mathrm{C}$, pH-value 8.0 and hydrocarbons concentration $2.0 \mathrm{~g} / \mathrm{l}$ in model ocean water of $35 \%$ salinity were found optimal for crude oil degradation.

- Acinetobacter sp. N3 strain could be used in varied salinity waters for oil hydrocarbons biodegradation.

Received 05 June 2014 Accepted 26 August 2014

\section{References}

1. Bao M, Wang L, Sun P, Cao L, Zou J, Li Y. Biodegradation of Crude Oil Using an Efficient
Microbial Consortium in a Simulated Marine Environment. Marine Poll Bull 2012.

2. British Petroleum Statistical Review of World Energy, June 2013.

3. Čipinytė V, Grigiškis S. Naftos ir jos produktų skaidymo naftą oksiduojančių mikroorganizmų asociacijomis tyrimas. APL inžiner 2000; 8(2): 74-78.

4. Das N, Chandran P. Microbial Degradation of Petroleum Hydrocarbon Contaminants: An Overview. Biotechnol Res Int 2011.

5. Doughari HJ, Ndakidemi PA, Human IS, Benade S. The Ecology, Biology and Pathogenesis of Acinetobacter spp.: An Overview. Microb Env 2011; 26(2): 101-12.

6. Fathepure BZ. Recent studies in microbial degradation of petroleum hydrocarbons in hypersaline environments. Front Microbiol 2014; 5.

7. Gavrilescu M. Environmental Biotechnology: Achievements, Opportunities and Challenges. Dynam Biochem, Process Biotechnol Molec Biol 2010; 4(1): 1-36.

8. Gedminienè G. 2006. Mikrobiologijos pagrindų laboratoriniai darbai. Vilnius: Technika.

9. HELCOM. 2014. Response to spill. Access from Internet $<\mathrm{http}: / /$ helcom.fi/action-areas/ response-to-spills/>.

10. Jankevičius K, Liužinas R. Aplinkos biologinis valymas. Vilnius: Apyaušris. 2003; 343 p.

11. Leahy JG, Colwell RR. Microbial Degradation of Hydrocarbons in the Environment. Microbiol Rev 1990; 54(3): 305-15.

12. Liu PWG, Chang TCh, Whang LM, Kao ChH, Pan PT, Cheng SS. Bioremediation of petroleum hydrocarbon contaminated soil: Effects of strategies and microbial community shift. Int Biodeterior Biodegrad 2011; 65: 1119-27.

13. Margesin R, Moertelmaier Ch, Mair J. Lowtemperature biodegradation of petroleum hydrocarbons (n-alkanes, phenol, anthracene, pyrene) by four actinobacterial strains. Int Biodeterior Biodegrad 2012; xxx: 1-7.

14. Prabhakaran P, Sureshbabu A, Rajakumar S, Ayyasamy PM. Bioremediation of Crude Oil 
in Synthetic Mineral Salts Medium Enriched with Aerobic Bacterial Consortium. Int J Innov Res Sci Engineer Technol 2014; 3(2): 9236-42.

15. Prince RC, McFarlin KM, Butler JD, Febbo EJ, Wang FCY, Nedwed TJ. The primary biodegradation of dispersed crude oil in the sea. Chemosphere 2013; 90: 521-26.

16. Rocha LL, Colares GB, Angelim AL, Grangeiro TB, Melo VMM. Culturable populations of Acinetobacter can promptly respond to contamination by alkanes in mangrove sediments. Marine Poll Bull 2013; 76: 214-19.

17. Ron E, Rosenberg E. Acinetobacter and Alkanindiges. Handbook of Hydrocarbon and Lipid Microbiology 2010.

18. Venosa AD, Zhu X. Biodegradation of Crude Oil Contaminating Marine Shorelines and Freshwater Wetlands. Spill Sci Technol Bull 2003; 8(2): 163-78.

19. Westermeyer WE. Bioremediation for Marine Oil Spills. Washington: Government Printing Office, 1991.
Elnara Fatajeva, Indrè Gailiūtė, Dainius Paliulis, Saulius Grigiškis

\section{ACINETOBACTER GENTIES MIKROORGA- NIZMŲ PANAUDOJIMAS NAFTOS ANGLIA- VANDENILIUS SKAIDANT DRUSKINGUOSE VANDENYSE}

\section{Santrauka}

Straipsnyje nagrinejjama naftos teršalų valymo problematika ir Acinetobacter genties mikroorganizmų panaudojimo skaidyti naftos teršalus. Tyrimų metu iš UAB „Biocentras“ mikroorganizmų kolekcijos buvo atrinktas geriausiai naftą ir mazutą druskinguose vandenyse skaidantis Acinetobacter genties mikroorganizmų kamienas bei îvertinta aplinkos sąlygų (druskingumo, temperatūros, $\mathrm{pH}$, substrato koncentracijos) ittaka šio kamieno gyvybingumui ir naftos skaidymo efektyvumui. Geriausiai Acinetobacter genties kamieno mikroorganizmai naftos produktus skaidè $30{ }^{\circ} \mathrm{C}$ temperatūroje, 7-8 pH verčių intervale, 35 \% modeliniame vandenyno vandenyje.

Raktažodžiai: Acinetobacter gentis, naftos angliavandeniliai, biologinis skaidymas, druskingas vanduo, jūrų tarša nafta ir jos produktais 